\title{
Tehlikeli Atık Bertaraf Tesislerinde Karşılaştırmalı Risk Analizi ve Biyolojik Faktörler Açısından Risk Değerlendirmesi
}

\author{
Hatice Ölçücü Şensoy ${ }^{1}$, İrem Ersöz Kaya ${ }^{2 *}$ \\ ${ }^{1}$ Tarsus Üniversitesi, Lisansüstü Eğitim Enstitüsü, İş Sağlı̆̆ ve Güvenliği Anabilim Dalı, Tarsus, Mersin, Türkiye \\ 2 Tarsus Üniversitesi, Teknoloji Fakültesi, Yazılım Mühendisliği Bölümü, Tarsus, Mersin, Türkiye
}

(İlk Geliş Tarihi 2 Aralık 2019 ve Kabul Tarihi 31 Aralık 2019)

(DOI: 10.31590/ejosat.668653)

ATIF/REFERENCE: Ölçücü Şensoy, H. \& Ersöz Kaya, İ. (2019). Tehlikeli Atık Bertaraf Tesislerinde Karşılaştırmalı Risk Analizi ve Biyolojik Faktörler Açısından Risk Değerlendirmesi. Avrupa Bilim ve Teknoloji Dergisi, (17), 1375-1382.

$\ddot{O} \mathbf{z}$

Sanayinin gelişmesi ve yaygınlaşması ile birlikte dünyadaki atık miktarı artmakta ve buna paralel olarak, atıkların oluşturduğu riskler ve zararlar da çoğalmaktadır. Tehlikeli atıkların verdiği zararın azaltılması için geri kazanım veya bertaraf yoluna gidilmesi gerekmektedir. Bu sebepten bertaraf tesislerinin sayısında bir artış yaşanmaktadır. Bu tip tesislerde çalışanlar, tehlikeli atıklarla uğraştıkları için birçok riske maruz kalmaktadırlar. Çalışmada, bir tehlikeli atık bertaraf tesisinde çalışanların atıkları aldıkları mesafelerden bertaraf süresine kadarki olan, maruziyet süreleri, vücutla teması, oluşan havanın solunması gibi etkiler incelenmiş ve biyolojik risk faktörleri araştırılmıştır. Bu faktörlerden meslek hastalığına sebep olan veya olabilmesi ihtimali bulunanlar değerlendirilmiş̧tir. Biyolojik risk analizinde, $5 \times 5$ L Tipi Matris yöntemi kullanılmıştır. Çalışmada ayrıca, fiziksel, kimyasal ve biyolojik risk faktörleri birlikte değerlendirilerek genel bir risk analizi yapılmış ve bunlara bağlı olarak hangi önleyici tedbirlerin alınması gerektiği belirlenmiş̧tir. Genel risk analizi değelendirmesinde, 5x5 L Tipi Matris yönteminin yanısıra Fine Kinney yöntemi kullanılmıştır. Analizler sonucunda iki metotta da 47 adet risk tespit edilmiştir. Fine Kinney risk analizine göre risklerin etki türüne göre dağılımı incelendiğinde en çok riskin 17 risk ile sağlık ve türevlerinden meydana geldiği tespit edilmiştir.

\section{Comparative Risk Analysis and Risk Assessment of Biological Factors in Hazardous Waste Disposal Facilities}

\begin{abstract}
The development and spread of the industry causes the amount of waste throughout the world to increase, accordingly leading to the increase of risks and damages caused by wastes. In order to reduce the damage caused by hazardous waste, it is necessary to implement recycling or disposal. Therefore, there is an increase in the number of disposal facilities. Employees working in such facilities are exposed to many risks as they deal with hazardous waste. In the study, the effects, such as exposure times, physical contact, inhalation of the air formed, on the employees working in a hazardous waste disposal facility, as exposed by whom starting from the waste collection until disposal process, were examined and biological risk factors were researched. Among such factors, those causing or likely to cause occupational disease were evaluated. The 5x5 L Type Matrix method was used in biological risk analysis. In addition, physical, chemical and biological risk factors were evaluated together and a general risk analysis was conducted and it was determined which preventive measures should be taken accordingly. In the assessment of general risk analysis, $5 x 5 \mathrm{~L}$ Type Matrix method as well as Fine Kinney methods were used. As a result of the analyses, 47 risks were found in both methods. Once the risks are distributed
\end{abstract}

\footnotetext{
*Sorumlu Yazar: Tarsus Üniversitesi, Teknoloji Fakültesi, Yazılım Mühendisliği Bölümü, Mersin, Türkiye, iremer@tarsus.edu.tr
} 
according to the type of impact as a result of the examination on the basis of Fine Kinney risk analysis, it is found that the type with the highest risk is health and its derivatives, which include 17 risks.

Keywords: Hazardous Waste, Occupational Diseases, Biological Risk, Risk Analysis, 5x5 L Type Matrix, Fine Kinney.

\section{Giriş}

Dünya üzerinde sürekli artan nüfus ve hızlı tüketim, teknoloji ile birlikte sanayileşmenin gelişmesini mecbur kılmıştır. Artan sanayileşme ülkelerin vatandaşlarını olumlu ve olumsuz yönde etkilemiştir. Fabrikalaşmanın artması, oluşan birçok atıkları ve iş kazalarını da birlikte getirmiştir. Sanayinin getirdiği iş kazaları, meslek hastalıkları ve atık miktarları iş sağlığ ve güvenliğinin önemini arttırmıştır. Sanayileşmenin gelişmesi ve küreselliğin artması beraberinde tehlikeleri doğurmakta, bu tehlikeler atık tehdidi olarak gelişmiş ülkelerden gelişmekte olan ülkelere doğru yönelmektedir. Tehlikelerin başlıcaları atıkların depolanmasının, geri dönüşümünün, geri kazanımının ve bertarafının yeterli olmamasıdır. Bilinçli ayrıştırma ve bilinçli tüketiminin yeterli yapılamaması atık miktarlarınıda günden güne arttırmıştır. Atık miktarlarının artmasıyla gelişen ülkelerde atık konusu büyük bir pazar haline gelmiştir. Büyük bir pazar haline gelen atık sektörü için de her ülkede geri dönüşüme önem günden güne artmıştır (Demirel ve Sert, 2018). Atıkların bertarafında ISO 9001 (Kalite) ve ISO 14001 (Çevre) standartları göz önünde bulundurulmuş, çevreye olumsuz etki değerleri bulunan, canlılara, toprağa, suya ve havaya zarar verebilecek tüm tehlike arz eden maddelerin taşınmasından bertarafına kadar tüm süreçlerin standartlara uygun biçimde gerçekleştirilmesi gerekmektedir (Akgün, 2006).

Atık sektörü kendi içinde birçok kategori bulundurmaktadır. Kategorik olarak ambalaj atık, tehlikeli atık, tehlikesiz atık, tıbbi atık gibi atık çeşitleri mevcuttur. Bu atıklarda kendi aralarında ayrılmış ve yaptığı iş koluna göre oluşabilecek atıklar için uygun atık kodları belirlenmiştir. Su savaşları olduğu gibi çöp savaşlarının da ortaya çıkması muhtemeldir. Gerek geri kullanılabilir malzemeye dönüşmesi gerek ikincil hammadde olarak kullanılması gerekse enerji elde edilmesi için oluşan atıklar bilinçli bir şekilde ayrıştırılmalıdır.

Katı atıklar, sağlık ve uygunluk yönünden atığın çeşidine uygun bir şekilde bertaraf edilmezlerse su, toprak ve hava kirliliğine neden olmaktadır. Tehlikeli olan ve yeterli düzeyde ayrıştırılmayan atıkların, gerekli kişisel koruyucu donanım malzemeler kullanılmadan taşınması ya da zararlı maaddelerin doğaya bırakılması ile bu işlerle uğraşan kişilerde solunan havadan, deriye temastan ve solunan kimyasallardan kaynaklı olarak akut ve kronik meslek hastalıkları oluşabilmektedir. Bu nedenlerden dolayı katı atıkların çevreye en az zarar verecek şekilde bertarafını sağlamak ve uygun bertaraf yöntemlerinin kullanılması gerekmektedir. Nüfus artışılla beraber, gelişen teknoloji ve kentselleşmeyle birlikte katı atıkların miktarları artmakta ve içerikleri giderek değişmektedir. Kaynakların ve doğanın zarar görmesi, ancak çevre kirliliğine neden olan etkenlerin azaltılması ile engelenebilmektedir. Geri kazanılabilir atıkların olduğundan daha fazla değerlendirilerek ekonomiye katkı sağlayan kaynak durumuna getirilmeleri gerekmektedir (Karagözoğlu, 2009).

Tehlikeli atık tesislerinde kimyasal ve fiziksel olarak oluşan maruziyet, biyolojik faktörlere göre daha fazladır. Atık tesislerinde çalışanlar için, fiziki olarak toza maruz kalma veya malzemenin düşmesi sonucu yaralanma; kimyasal risk olarak atığın elle taşınması esnasında dökülen kimyasal maddeden zarar görme; biyolojik olarak ise bakteriyel kaynaklı riskler gibi tehlikeler bulunmaktadır (Kayhan ve Demirer, 2016). Tehlikeli atık tesislerinde oluşan bu riskler meslek hastalıklarının ortaya çıkmasına da sebep olabilmektedir. Meslek hastalığı; iş koluyla alakalı risk taşıyan alanlarda, uzun zaman maruz kalınması sonucu oluşmaktadır. Meslek hastalığı çalışanların yaşam şekillerini ve sağlıklarını olumsuz yönde etkileyen bir unsurdur. Zamanla oluşan hastalıklar neticesinde hayatlar yok olmakta, kaybedilen uzuvlar ve ortaya çıkan manevi zorluklar sonucu yok olan insan gücü tekrar geri getirilememektedir. Meslek hastalığının artması ve yaşamların yok olması sonucu, iş yerlerinde iş sağlığının önemi ve gerekliliği artmıştır. İşçi sağlığı ve iş güvenliğinin temel amaçları arasında; çalışanların fiziksel ve psikolojik yönden sağlığının korunması için gerekli ergonomik ortamın sağlaması ve sürdürülmesi; çalışma koşullarından kaynaklanabilecek olumsuz sonuçların önlenmesi ve her türlü sağlık sorunundan korunması yer almaktadır. Bu nedenle, işçi sağlığı ve iş güvenliğinde, temelde risklerin ortaya çıkmadan önlenmesi amaçlanmaktadır. Bunun için öncelikle risk analizinin yapılarak risklerin ortaya çıkarılması ve alınması gerken önlemlerin belirlenmesi gerekir (Şengöz ve Merdan, 2017).

Yapılan bu çalışmada, tehlikeli atık tesislerindeki biyolojik risk faktörleri ile meslek hastalığının oluşmasına sebep olan fiziksel, kimyasal ve biyolojik etmenler incelenmiştir. Gözlemler-araştırmalar kapsamında atık tesislerinde neler meslek hastalı̆̆ı olarak nitelendirilmektedir, çalışanlar hangi tür risk faktörlerine maruz kalmaktadır gibi soruların cevapları araştırılmıştır. Sorulara verilen cevaplar doğrultusunda meslek hastalıkları/iş kazalarının önlenmesi veya azaltılması yönünde alınacanak tedbirler konusunda önerilerde bulunulmuştur. Tehlikeli atık tesislerinde fiziksel ve kimyasal risk faktörlerinin daha fazla olması, biyolojik açıdan oluşabilecek risk faktörlerinin incelenmesi konusunda yeterli çalışmanın olmaması bu konu hakkında çalışma eğilimini arttırmıştır.

Yapılan çalışmalar incelendiğinde, çevre kirliliği ve atık konusunun önemini vurgulayan bir çalışmada Akgün, enerji birimlerinin katı, sıvı ve gaz atık olarak toprağa, havaya, suya bırakılması sonucu sanayi atıkları sorununun ortaya çıktığınıve Endüstriyel atıkların meslek hastalıklarına neden olduğunu belirtmiştir (Akgün, 2006). Kayhan ve Demirer (2016) ise yaptıkları çalışmada polimer işleme sektöründe, polimeri plastik imalat sektörüne indirgeyerek, bu kollardaki meslek hastalıklarından korunma yöntemlerini ve risk değerlendirmesinin nasıl yapılacağı araştırmışlardır. Risk teşkil eden fiziksel, kimyasal ve biyolojik faktörlerin tespit edilmesinde hangi tedbirlerin alınması gerektiğini incelemişlerdir. Meslek hastalıklarının önlenmesi veya azaltılmasında konusunda, çalışanlara ve işverene düşen yükümlülüklerin neler olabileceğini ele almışlardır. Bir diğer çalışmada Ercan (2006), üç farklı bertaraf tesisinde atıkların taşınmasından imha ve geri kazanımına kadar olan süreçleri inceleyerek tehlikeli atık bertaraf metotlarını ve tesiste ortaya çıkabilecek riskleri araştırmıştır. Benzer bir çalışmada Akkuş (2013), tehlikeli atık geri kazanım tesisinde iş güvenliği açısından ortaya çıkabilecek tehlike ve riskleri analiz ederek kabul edilebilir seviyelerde tutabilmek amacıyla alınması gereken önlemleri belirlemiştir. 
$\mathrm{Bu}$ çalışma, Mersin ilinde faaliyet gösteren bir tehlikeli atık geri kazanım tesisi çalışanları üzerinde yapılan analizleri kapsamaktadır. Çalışmanın ilk aşamalarında atıklarla ile ilgili tüm bilgiler toplanmış, belirlenen bertaraf tesisi ve atıkların depolandığı saha alanında gözlem yapılmıştır. Araştırmada, bu zamana kadar tesise hizmet veren Ortak Sağlık ve Güvenlik Birimi (OSGB)'lerden kayıtlı teşhis verileri alınarak atığın tesise taşınması, nerelerden alındığı, transferi (maruziyet süresi), imha edilmesi ve ayrıştırılmasına kadar geçen süre değerlendirilmiştir. Bu değerlendirmede, 2015 yılından bu yana tutulan sağlık raporları esas alınmıștır. Tesise gelen atıklar ve içerikleri ile ilgili raporlar ve dosyalar incelenerek malzemelerin insan vücudundaki etkileri, temasla ve solumayla biyolojik açıdan nasıl riskler taşıdığı analiz edilmiştir. Günlük ve aylık ortalama gelen atık miktarları, ilgili bakanlığın oluşturduğu atık yönetim uygulaması portalına giriş yapılarak belirlenmiş, çalışanların maruziyet süreleriyle orantılı olarak oluşabilecek meslek hastalıkları tespit edilmiş ve bu kayıtlarla 5x5 L Tipi Matris yöntemi kullanılarak bir risk analizi yapılmıştır. Bu hastalıklar, kayıtlara geçmiş olanlar referans alınarak firma sahibi, tesis yetkilisi, doktor ve uzman eşliğinde yapılan çalışmalarla belirlenmiştir. Bununla birlikte, fiziksel, kimyasal ve biyolojik faktörler birlikte değerlendirmeye alınarak genel bir risk analizi yapılmıştır. Tüm faktörler için mevcut riskler ve sebep olabilecekleri meslek hastalıkları belirlenmiştir. Genel değerlendirme için 5x5 L Tipi Matris ve Fine Kinney yöntemleri uygulanmış ve iki yönteminin analiz sonuçları birbirleri ile karşılaştırılmıştır. Yapılan risk analizlerinden elde edilen veriler doğrultusunda, atık bertaraf tesislerinde ortaya çıkabilecek risklerin azaltılması amacıyla alınması gereken önlemler ortaya konulmuş̧ur.

\section{Materyal ve Metot}

$\mathrm{Bu}$ çalışmada atığın alınmasından bertarafına kadar geçenki sürede oluşabilecek risklerin belirlenmesi amaçlanmıştır. Tesiste risk teşkil eden her materyal teşhiş edilerek gerekli önlemlerin alınabilmesi için risk analizi yapılmıştır. Risk analizlerinde, biyolojik risk faktörleri için 5x5 L Tipi Matris, fiziksel, kimyasal ve biyolojik risk faktörlerinin genel değerlendirmesi içinse 5x5 L Tipi Matris ile Fine Kinney yöntemleri kullanılmıştır.

Çalışmaların yapılacak olduğu firmaya bağlı iki tesiste toplam 30 kişi çalışmaktadır. Tehlikeli atık tesisinde çalışan sayısı ise 15 'dir. Tehlikeli atık tesisi çalışanları çalışma dağılımında; 5 kişi idari binada, 10 kişi ise saha elemanı olarak çalışmaktadır. Kamu kurum ve kuruluşlarından alınan veya çeşitli sektörlerle ilgilenen işletmelerden çıkan atıklar, Çevre ve Şehircilik Bakanlığından alınan lisans kapsamında bulunuyorsa tesise kabulü yapılmaktadır. İşletmede mevcutta var olan atıkların ve piyasadan kabul edilen atıkların geri kazanım işlemi gerçekleştirilmektedir.

\subsection{5x5 L Tipi Matris Risk Değerlendirme Yöntemi}

Risk analizi yöntemlerinden 5x5 L Tipi Matris, daha çok sebep-sonuç (neden-sonuç) ilişkilerinin belirlenmesinde kullanılan bir yöntemdir. Bu metot ile öncelikle bir olayın gerçekleşme ihtimali ile gerçekleşmesi halinde neleri doğurabileceğinin derecelendirilmesi yapılır. Risk değeri, olasılık ve şidddet (etki) değerlerinin çarpılmasılyla hesaplanır;

$$
\text { Risk }=\text { Olasılık } x \text { Şiddet }
$$

burada olasılık, bir olayın belirli zaman dilimleri içerisinde gerçekleşme durumunu; şiddet ise tehlikenin oluşması durumunda iş yerinde ortaya çıkacak zararın derecesini göstermektedir (Usanmaz ve Köse, 2019).

Şiddet değeri (soldan sağa) ve olasılık değeri (yukarıdan aşağıya) doğru numaralandırılarak tabloya yazılır. Şiddet ve olasılık düzeylerinnin en düşük değeri 1 , en yüksek değeri ise 5 'tir. Sırayla verilen yatay ve dikey değerler birbiri ile çarpılarak her bir olayın risk puanı hesaplanır. Puanların hesaplanmasında kullanılacak olasılık ve şiddet derecelendirme tabloları, sırasıyla Tablo 1 ve Tablo 2'de verilmektedir.

Tablo 1. 5x5 L Tipi Matris yöntemi şiddet değerlendirme tablosu

\begin{tabular}{l|l|c}
\hline Derece & Şiddet & Puan \\
\hline Çok Hafif & İş Saati Kaybı Yok - Sadece İlkyardım & 1 \\
\hline Hafif & İş Günü Kaybı Yok - İlkyardım veya Tıbbi Tedavi & 2 \\
\hline Orta & İş günü Kayıplı Kaza - Hafif Yaralanma & 3 \\
\hline Ciddi & Uzuv Kaybı, Ağır Yaralanma - Uzun Süreli Tedavi & 4 \\
\hline Çok Ciddi & Ölüm, Çevresel Felaket & 5 \\
\hline
\end{tabular}

Tablo 2. 5x5 L Tipi Matris yöntemi olasllık değerlendirme tablosu

\begin{tabular}{l|l|c}
\hline Derece & Olasılık & Puan \\
\hline Çok Küçük & Neredeyse Mümkün Değil (Yılda Bir) & 1 \\
\hline Küçük & Az Olasılıkla (Yılda Birkaç Kez) & 2 \\
\hline Orta & Olasılık Dâhilinde (Ayda Bir) & 3 \\
\hline Yüksek & Yüksek Olasılık (Haftada Bir) & 4 \\
\hline Çok Yüksek & Kaçınılmaz (Her Gün) & 5 \\
\hline
\end{tabular}

5x5 L Tipi Matris yönteminde, olasılık ve şiddet puanları kullanılarak elde edilen risk değerleri, Tablo 3'de verilen matrise göre derecelendirilmektedir. 
Tablo 3. 5x5 L Tipi Matris yöntemi risk değerlendirme tablosu

\begin{tabular}{|c|c|c|c|c|c|c|}
\hline & \multicolumn{5}{|c|}{ Şiddet } \\
\hline & & Çok Hafif (1) & Hafif (2) & Orta (3) & Ciddi (4) & Çok Ciddi (5) \\
\hline \multirow{5}{*}{$\begin{array}{l}\frac{1}{\bar{E}} \\
\text { 产 } \\
\end{array}$} & Çok Küçük (1) & 1 & 2 & 3 & 4 & 5 \\
\hline & Küçük (2) & 2 & 4 & 5 & 8 & 10 \\
\hline & Orta (3) & 3 & 6 & 9 & 12 & 15 \\
\hline & Yüksek (4) & 4 & 8 & 12 & 16 & 20 \\
\hline & Çok Yüksek (5) & 5 & 10 & 15 & 20 & 25 \\
\hline
\end{tabular}

Dikey konumlandırma (olasılık) ve yatay konumlandırma (şiddet) çarpımıyla elde edilen puanların açıklaması aşağıda verilmektedir;

1-2 Puan: Önemsiz olarak nitelendirilir. Pek fazla önem arz etmeyen, kabulü yapılabilen risklerdir.

3-6 Puan: Katlanılabilir olarak nitelendirilir. Uzun dönemde oluşan dikkat gerektiren, katlanılabilir risk grubudur.

8-12 Puan: Orta düzey olarak nitelendirilir. Önem arz eden, kısa dönemde önlem alınması gereken risklerdir.

15-16 Puan: Önemli olarak nitelendirilir. Son derecede önem arz eden, anında önlem alınması gereken risk grubudur.

20-25 Puan: Katlanılamaz olarak nitelendirilir. Herhangi bir tedbir alınmadan işe başlanmasının kabul görmediği risk grubudur.

5x5 L Tipi Matris yöntemi, hassas olmamasına rağmen basit ve kolay uygulanabilir olması açısından risk analizi yapmak zorunda olan işletmeler için idealdir ve bu nedenle, yaygın bir şekilde kullanılır (Demirel, 2016). Genelde az tehlikeli ve tehlikeli çalışma alanlarının değerlendirilmesinde tercih edilmektedir (Zaloğlu, 2019).

\subsection{Fine Kinney Risk Değerlendirme Yöntemi}

Fine Kinney, risk derecelerinin ve bu derecelere göre hangi tedbirlerin alınması gerektiğinin belirlenmesi amacıyla kullanılan bir risk analizi yöntemidir. Bu yöntemde risk düzeyi hesaplanırken olasılık, şiddet ve frekans olmak üzere üç parametre değerlendirmeye alınır (Oturakçı ve Dağsuyu, 2017). Fine kinney’de 5x5 L Tipi Matristen farklı olarak frekans faktörü bulunmaktadır. Bununla birlikte, şiddet ve olasılık faktörlerinin puan skalası da 5x5 L Tipi Matris yöntemine göre farklılık göstermektedir. Fine Kinney yönteminde şiddet 1 ile 100 arası bir değer alırken, olasılık 0,2 ile 10 arasında değişmektedir.

Fine Kinney’e göre risk puanı aşağıdaki şekilde hesaplanır;

$$
\text { Risk }=\text { Olasıllk } x \text { Şiddet } x \text { Frekans }
$$

burada frekans faktörü, belirli bir zaman içerisinde tehlikeye maruz kalmanın ne kadar tekrarlandığını ifade etmektedir. Frekans puanı, 0,5 ile 10 arası bir değer almaktadır ve altı kategoriden oluşmaktadır. Olasılık değeri bulunurken, bir hasarın veya zararın ortaya çıkma ihtimali göz önüne alınaktadır. Şidddet fakörü ise kişilerin, iş yerinin veya çevrenin etkilenme derecesine göre değerlendirilmektedir. Fine Kinney'de olasılık, şiddet ve frekans derecelendirme tabloları, sırasıyla Tablo 4, Tablo 5 ve Tablo 6'da verilmektedir.

Tablo 4. Fine Kinney yöntemi şiddet değerlendirme tablosu

\begin{tabular}{l|c}
\hline Şiddet & Puan \\
\hline Ramak Kala - Çevresel Zarar Yok & 1 \\
\hline Küçük Hasar, Yaralanma, İlkyardım - Sınırlı Çevresel Etki & 3 \\
\hline Önemli Hasar, Yaralanma, Tıbbi Tedavi- Geniş Çevresel Etki & 7 \\
\hline Kalıı Hasar, Sakatlık, Uzun Süreli Tedavi - Önemli Çevresel Etki & 15 \\
\hline Ölüm - Ciddi Çevresel Etki & 40 \\
\hline Birden Fazla Ölüm - Çevresel Felaket & 100 \\
\hline
\end{tabular}

Tablo 5. Fine Kinney yöntemi olasılık değerlendirme tablosu

\begin{tabular}{l|c}
\hline Olasılık & Puan \\
\hline Pratik Olarak İmkânsız-Beklenmeyen & 0,2 \\
\hline Mümkün Ancak Beklenmeyen & 0,5 \\
\hline Mümkün Ancak Düşük İhtimal & 1 \\
\hline Mümkün & 3 \\
\hline Oldukça Mümkün & 6 \\
\hline Kesin, Beklenir & 10 \\
\hline
\end{tabular}


Tablo 6. Fine Kinney yöntemi frekans değerlendirme tablosu

\begin{tabular}{l|c}
\hline Frekans & Puan \\
\hline Çok Seyrek (Yılda bir veya daha az) & 0,5 \\
\hline Seyrek (Yılda birkaç defa) & 1 \\
\hline Nadiren (Ayda bir veya birkaç defa) & 2 \\
\hline Ara Sıra (Haftada bir veya birkaç defa) & 3 \\
\hline Sik (Günde bir veya birkaç defa) & 6 \\
\hline Sürekli (Saatte birkaç defa) & 10 \\
\hline
\end{tabular}

Fine Kinney yönteminde, bir riskin gerçekleşme olasılığ1, tehlikeye maruz kalma sıklığ1 ve şiddet derecesi göz önüne alınarak hesaplanan risk değeri (R) aşağıdaki tabloda verilen sınıflandırmaya göre değerlendirilir (Tablo 7).

Tablo 7. Fine Kinney yöntemi risk değerlendirme tablosu

\begin{tabular}{l|l}
\hline Risk Değeri & Risk Sınıflandırması \\
\hline $\mathrm{R}<20$ & Önemsiz (Düşük Risk) - Kabul edilebilir \\
\hline $20<\mathrm{R}<70$ & Olası Risk - Uzun vadede önlemler alınıp iyileştirilmelidir ve gözetim altında tutulmalıdır \\
\hline $70<\mathrm{R}<200$ & Ciddi Risk - Kkısa dönemde iyileştirilmelidir \\
\hline $200<\mathrm{R}<400$ & Kritik Risk - Çok kısa sürede iyileştirilmelidir \\
\hline $\mathrm{R}>400$ & Kabul Edilemez Risk - İyileşene kadar işe ara verilmelidir \\
\hline
\end{tabular}

Risk değerinin 20’den az bulunması durumunda risk kabul edilebilir seviyededir ve önemsiz risk olarak kabul edilir. Risk değerinin 20 ile 70 arasında olması durumunda, bu aralıktaki riskler için herhangi bir yasal gereklilik yoksa tedbir alınması gerekmemektedir. Bu durumda var olan koruma tedbirlerinin sürdürülmesine devam edilmeli ve uzun dönemde iyileştirmeler yapılmalıdır. Riskin ortaya çıkma potansiyeli göz önünde bulundurularak, risklerin oluşmaması için çalışma ortamı sürekli gözetim altında tutulmalıdır. Risk değerinin 70 ile 200 arasında olması durumunda ise ciddi risk ortaya çıkmaktadır. Bu risklerde düzeltici/önleyici önlemler alınarak, kısa dönemde iyileştirme yapılmalıdır. Risk düzeyinin 400’den fazla çıkması durumunda kabul edilemez risk oluşmaktadır. Bu risk durumunda, insan ve çevre sağlığını tehdit eden tehlikeyle ilgili iyileştirme yapılıncaya kadar işin durdurulması gerekmektedir.

\section{Araştırma Sonuçları ve Tartışma}

Çalışmanın yapıldığı tesis, tehlikeli/tehlikesiz atık toplama üzerine faaliyet göstermektedir. İşletmenin faaliyetleri, atığın lisanslı bir araçla tesise getirilmesi ile başlamaktadır. Tesise gelen lisanslı araç tesis girişinde; görsel kontrole, atık kodu kontrolüne, sürücü ve araç belgeleri kontrolüne, atık belgeleri (beyan formları, kantar fişi, irsaliye) kontrolüne tabi tutulmaktadır. Kontroller sonucunda uygunsuzluk tespit edilen atıklar tesise kabul edilmemektedir. Kontroller sonucunda uygun olan araçların, seyyar radyasyon cihazı ile ölçümü yapılmaktadır. İşlemler sonucu tesise kabul edilen atık araçları, boşaltılmak üzere tesise yönlendirilmektedir. Tesise her sektörden, özellikle hastane, metal, kimya sanayinden atıklar gelmektedir. Gelen malzemenin cinsine göre gerekli ön işlemler (yıkama, kesme vb.) yapılmaktadır. Metal ambalajlı atıkların (varil, bidon vb.) içindeki ilaç, boya, tiner, deterjan hammaddelerinin kullanılması sonucu ambalajda kalıntılar olması ve ambalajlara yağ, ilaç bulaşması sonucu tehlikeli atıklar oluşmaktadır. Tehlikeli atıkların taşınmasından bertarafına kadar geçen süreçte iş kazaları ve meslek hastalıklarına sebep olabilecek fiziksel, kimyasal ve biyolojik risk faktörleri ortaya çıkmaktadır. Atıkların taşınması, yüklemesi, boşaltılması, manuel söküm ve kesme-biçim işlemlerinde yaralanmalar yaşanabilmektedir Tehlike kaynaklarına göre tehlikeli atık tesislerinde çalışanlarda; gürültüden kaynaklı işitme kayıpları, radyasyon etkisi ile genetik bozukluklar, titreşime bağlı olarak beyaz parmak hastalığı, aydınlatmaya bağlı olarak görme bozuklukları, sıcaklığa bağlı rahatsızlıklar, kimyasal maddelere maruz kalma, toz ve kimyasallardan kaynaklı solunum rahatsızlıkları, alerjik durumlar, vücutta yanıklar, viral enfeksiyonlar, bakteriyel kaynaklı hastalıklar (burucellozis, pnömoni, tüberküloz vb.) ve yüzeysel deri lezyonları gibi rahatsızlıklar meydana gelebilmektedir.

Atık bertaraf tesisleri, Biyolojik Etkenlere Maruziyet Risklerinin Önlenmesi Hakkında Yönetmelik'e göre atık bertaraf tesisleri biyolojik risk etmenleriyle karşılaşılması muhtemel iş ortamları arasında sayılmaktadır. Araştırma konusu tesisteki biyolojik risk faktörlerinin değerlendirilmesi ve meslek hastalıkları ile ilişkisinin araştırılması amacıyla öncelikle atıklarla ile ilgili tüm bilgiler toplanmış, belirlenen bertaraf tesisi ve atıkların depolandığı saha alanında gözlem yapılmıştır. Tesise gelen atıklar ve içerikleri ile ilgili raporlar ve dosyalar incelenerek malzemelerin insan vücudundaki etkileri, temasla ve solumayla biyolojik açıdan nasıl riskler taşıdığı analiz edilmiştir. Genel olarak biyolojik risk faktörleri, 4 gruptan oluşmaktadır;

Grup 1: İnsanda hastalığa yol açma ihtimali olmayan biyolojik etkenler.

Grup 2: İnsanda hastalığa neden olabilen, çalışanlara zarar verebilecek, ancak topluma yayılma olasılığı olmayan, genellikle etkili korunma veya tedavi imkânı bulunan biyolojik etkenler.

Grup 3: İnsanda ağır hastalıklara neden olan, çalışanlar için ciddi tehlike oluşturan, topluma yayılma riski bulunabilen ancak genellikle etkili korunma veya tedavi imkânı olan biyolojik etkenler. 
Grup 4: İnsanda ağır hastalıklara neden olan, çalışanlar için ciddi tehlike oluşturan, topluma yayılma riski yüksek olan ancak etkili korunma ve tedavi yöntemi bulunmayan biyolojik etkenler.

Tehlikeli atık bertaraf/geri kazanım tesislerinde yapılan işler ve iş süreçleri göz önüne alındığında, tesiste ortaya çıkabilecek biyolojik risk faktörlerinin Grup 1 ve Grup 2'de yer alabileceği değerlendirilmiştir. Çalışmada öncelikle, bu gruplarda yer alan biyolojik risk faktörlerinin meslek hastalığına sebep olup olamayacağı araştırılmıştır. Bunun için, bu zamana kadar tesise hizmet veren Ortak Sağlık ve Güvenlik Birimi (OSGB)'lerden kayıtlı meslek hastalığı teşhis verileri alınarak, meslek hastalıklarının, atığın tesise taşınması, nerelerden alındı̆̆ı̆, transferi (maruziyet süresi), imha edilmesi ve ayrıştırılmasına kadar geçen süreçlerde ortaya çıkabilecek biyolojik risk faktörleri ile olan ilişkisine bakılmıştır. İnceleme sonucunda meslek hastalığı ve biyolojik faktörler arasında bir ilişki bulunamamıştır.

Çalışmanın ilk aşamasında, biyolojik risk faktörleri ile meslek hastalıklarına sebep olabilecek biyolojik risk faktörleri, 5x5 L Tipi Matris yöntemi kullanılarak analiz edilmiştir. Analiz sonucunda, tesiste yapılan işlerde, biyolojik faktörlerden kaynaklı 11 adet risk belirlenmiştir. Bu risklerin 9 tanesi 2.kategoride yani orta risk grubunda, 2 tanesi ise 3. kategori yani düşük risk grubunda yer almaktadır. Örneğin, akü parçalama esnasında çalışanın, kurşun, cıva gibi ağır metalleri solunması durumunda, $5 \times 5$ L Tipi Matris yöntemine göre olasılığı 3, şiddeti 3 olduğundan risk skoru 9 bulunmuştur; 2. kategoride yani orta risk grubundadır. Bir diğer örnekte ise müşterek kullanılan tuvalet ve duşlarda bir çalışandan diğer bir çalışana hastalık bulaşması $5 \times 5 \mathrm{~L}$ Tipi Matris yöntemine göre değerlendirildiğinde, olasılığı 3 , şiddeti ise 5 olduğundan risk skoru 15 olarak elde edilir. Buna göre 15 risk skoru 2. Kategoride, orta risk grubunda yer almaktadır. Bu yöntemde, orta riskler için kısa dönemde iyileştirme yapılması, düşük riskler için ise uzun dönemde iyileştirme yapılması ve gözetim altında tutulması gerekmektedir.

Çalışmanın ikinci aşamasında, 5x5 L Tipi Matris ve Fine Kinney yöntemleri kullanılarak genel bir risk analizi yapılmıştır. Genel riskler 3 kategoride fiziksel, kimyasal, biyolojik faktörler yönünden incelenmiştir. Risklerin belirlenmesinde, sorumlu OSGB tarafından kitle-iletişim araçları yoluyla yapılmış mevcut anketler kullanılmış; çalışanlar ve uzmanlar tarafından işaretlenen riskler seçilmiştir. Tehlikeli atık bertaraf tesisinde yapılan risk değerlendirmesi analizi sonucunda iki metotta da 47 adet risk tespit edilmiştir. $5 \times 5 \mathrm{~L}$ Tipi Matris yöntemine göre yapılan risk değerlendirmesinde, 47 adet riskten, 27 tanesinin yüksek risk, 13 tanesinin orta risk, 7 tanesinin ise düşük risk grubunda olduğu belirlenmiştir. Fine Kinney yöntemine göre ise tespit edilen 47 adet riskin; 21 tanesi ciddi risk, 21 tanesi olası risk, 2 tanesi kritik risk, 3 tanesi ise düşük risk grubundadır. Buna göre, toplam risklerin \%4'ünün kritik risk (200-400), \%45'inin ciddi risk (70-200) \%51'inin olası risk (20-70) ve düşük risk (0-20) olduğu görülebilmektedir (Şekil 1). Analizlerde, elde edilen risk durumlarına göre alınması gereken önlemler belirlenmiştir (Ölçücü Şensoy, 2019). Riskler etki türüne göre değerlendirildiğinde, en fazla riskin sağlık ve türevlerinden kaynaklandığı tespit edilmiştir. Her iki yöntemle yapılan analizler sonucunda belirlenen risklerden bazıları Tablo 8'de verilmektedir. Verilen örnek durumlar için önerilen önlemler sonrasında risk derecelerinin ne ölçüde azalacağı da Tablo 8'de belirtilmektedir.

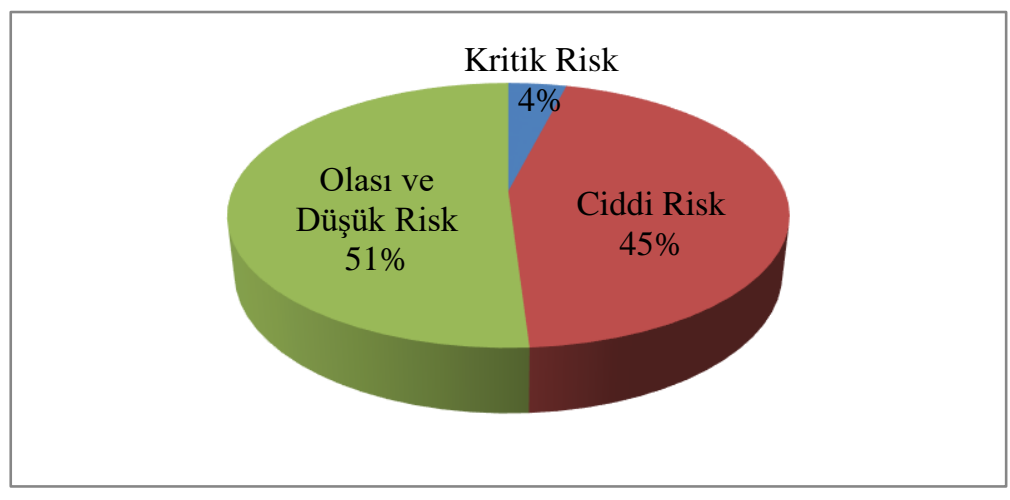

Şekil 1. Genel risklerin düzeylerine göre dağılımı

İki yöntemle yapılan risk değerlendirmesinde farklı işler için farklı risk değerlerinin elde edildiği durumlar ortaya çıkmıştır. Fine Kinney yönteminde frekans faktörü devreye girdiğinden sıklıkla tekrar edilen işlerde sonuçlar farklı çıkabilmektedir. Örneğin uzun süreli kaynak dumanının soluması sonucu akciğer rahatsızlığının ortaya çıkması durumu için risk skoru, 5x5 L Tipi Matris yöntemine göre 12'dir. Bu orta düzey risk grubuna girmektedir. Ancak Fine Kinney yönteminde biraz daha detaylandırıp o riskin zaman içerisinde ne sıklıkla yaşandığı da değerlendirmeye alındığından daha ayrıntılı bir risk analizi ortaya çıkar ve buna göre, olasılık 3 , şiddet 40 ve frekans 1 (ayda 1 veya birkaç defa oluşması) olmak üzere risk skoru 120 elde edilir. Bu durum ise ciddi risk grubuna girmektedir. Bu grup riskleri için kısa sürede tedbirler planlanmalı ve gerçekleştirilmelidir, kapatma ve durdurma önerilmez. 5x5 L Tipi Matris yöntemine göre ise belirlenen riskleri düşürmek için faaliyetlerin başlatılması gerektiği sonucu ortaya çıkmıştır.

Bir başka örnek olarak, kesikler ve yaralanmalar sonucu kan ile bulaşabilecek virüslerin (hiv, hepatit $\mathrm{b}$, hepatit $\mathrm{c}$ vb.) diğer çalışanlara bulaşması durumu ele alındığında, $5 \times 5$ L Tipi Matris yönteminde, olasılığ 4 , şiddeti 4 olduğundan risk skoru 16 olmaktadır. Aynı risk için, Fine Kinney yönteminde ise olasılık 3, şiddet 40, frekans 1 (ayda 1 veya birkaç defa oluşması) olmak üzere risk skoru 120 elde edilmektedir. Bu skora göre risk, ciddi olarak değerlendirilmektedir. Fine Kinney’e göre, risk değerinin 70 ile 200 arasında olması durumunda düzeltici/önleyici önlemler alınarak, kısa dönemde iyileştirme yapılması gerekmektedir. Bu risk 5x5 L Tipi Matris yönteminde ise önemli risk grubunda yer almaktadır. Önemli risk grubuna giren riskler için belirlenen risk azaltılıncaya kadar iş başlatılmamalı eğer devam eden bir faaliyet varsa derhal durdulmalıdır. Risk için acil önlemler alınmalı ve bu önlemler sonucunda faaliyetin devam edip etmeyeceğine karar verilmelidir. 
Tablo 8. 5x5 L Tipi Matris ve Fine Kinney risk değerlendirme sonuçlarl

\begin{tabular}{|c|c|c|c|c|c|}
\hline \multirow[b]{2}{*}{ Tehlike/Risk Durumu } & \multirow[b]{2}{*}{ Alınacak Önlemler } & \multicolumn{2}{|c|}{ 5x5 L Tipi Matris } & \multicolumn{2}{|c|}{ Fine Kinney } \\
\hline & & $\begin{array}{l}\text { Başlangıç } \\
\text { Riski }\end{array}$ & $\begin{array}{c}\text { Kalan } \\
\text { Risk }\end{array}$ & $\begin{array}{l}\text { Başlangıç } \\
\text { Riski }\end{array}$ & $\begin{array}{c}\text { Kalan } \\
\text { Risk }\end{array}$ \\
\hline $\begin{array}{l}\text { Kesikler ve yaralanmalar sonucu kan } \\
\text { ile bulaşabilecek virüslerin (hiv, } \\
\text { hepatit b vb.) diğer çalışanlara } \\
\text { bulaşması }\end{array}$ & $\begin{array}{l}\text { Deriyi kesebilecek delecek aletler } \\
\text { kullanılırken veya açı, kanayan } \\
\text { yara/kesiklerin bulunması durumunda } \\
\text { eldiven kullanılmalıdır. }\end{array}$ & 16 & 4 & 120 & 8 \\
\hline $\begin{array}{l}\text { Aynı ortamda yatan personellerin } \\
\text { solunum yolu ile birbirlerine hastalık } \\
\text { bulaştırması }\end{array}$ & $\begin{array}{l}\text { Yatakhaneler düzenli aralıklarla } \\
\text { temizlenmeli, havalandırılmalı ve } \\
\text { periyodik aralıklarla sağlık tetkikleri } \\
\text { yapılmalıdır. }\end{array}$ & 16 & 4 & 120 & 8 \\
\hline $\begin{array}{l}\text { Yanlış taşıma yöntemleri kullanılmas1 } \\
\text { sonucu bel/boyun rahatsızlıklarının } \\
\text { ortaya çıması }\end{array}$ & $\begin{array}{l}\text { Yönetmeliğe uygun taşma yöntemleri } \\
\text { uygulanmalıdır. }\end{array}$ & 16 & 4 & 120 & 8 \\
\hline $\begin{array}{l}\text { Uzun süreli kaynak dumanının } \\
\text { solunması sonucu kalıcı akciğer } \\
\text { rahatsızlığının ortaya çıkması }\end{array}$ & $\begin{array}{l}\text { Kaynak esnasında standartlara uygun } \\
\text { maske kullanılmalı, düzenli } \\
\text { aralıklarla mola verilmeli ve } \\
\text { havalandırma yapılmalıdır. }\end{array}$ & 16 & 4 & 120 & 8 \\
\hline $\begin{array}{l}\text { Yangın mücadele ekipmanlarının } \\
\text { kolay erişilir yerde olmaması, } \\
\text { müdahale güçlügü }\end{array}$ & $\begin{array}{l}\text { Yönetmelik geregince yangın } \\
\text { tüplerinin yerden yüksekligi } 90 \mathrm{~cm}- \\
120 \mathrm{~cm} \text { arasında olması sağlanmalıdır }\end{array}$ & 16 & 4 & 300 & 10 \\
\hline $\begin{array}{l}\text { Uzatma kablolarının yerden veya sulu } \\
\text { zeminden geçmesi }\end{array}$ & $\begin{array}{l}\text { Uzatma kabloları kablo kanallarından } \\
\text { geçirilmelidir. }\end{array}$ & 16 & 4 & 60 & 10 \\
\hline $\begin{array}{l}\text { Ekranlı araçlarla çalışma yapan } \\
\text { personelin periyodik göz } \\
\text { muayenelerinin takip edilmemesi }\end{array}$ & $\begin{array}{l}\text { Ekranlı araçlarla çalışma yapan } \\
\text { personelin periyodik göz muayeneleri } \\
\text { yapılmalıdır. }\end{array}$ & 9 & 4 & 45 & 3,75 \\
\hline $\begin{array}{l}\text { Çalışan personele tetonaz aşısı } \\
\text { yaptırılmaması }\end{array}$ & $\begin{array}{l}\text { Tüm çalışanlra tetanoz aşısı } \\
\text { yaptırılmalı, aşı kartı özlük } \\
\text { dosyalarında saklanmalıdır. }\end{array}$ & 12 & 4 & 75 & 1,5 \\
\hline $\begin{array}{l}\text { Yangın techizatının periyodik } \\
\text { kontrollerinin yapılmamas1 }\end{array}$ & $\begin{array}{l}\text { Yönetmelik gereğince yangın } \\
\text { tüplerinin periyodik olarak yılda en } \\
\text { az bir defa kontrol edilmesi } \\
\text { saglanmalıdır. }\end{array}$ & 12 & 4 & 120 & 20 \\
\hline
\end{tabular}

Genel olarak bir değerlendirme yapıldığında iki metot arasındaki farkın büyük oranda frekans faktöründen kaynaklandığı ileri sürülebilir. Elde edilen sonuçlar karşılaştırıldığında, $5 * 5$ matrisin puan skalası daha kısıtlı olduğundan, Fine Kinney yöntemine göre daha dar aralıklara hitap etmektedir. Fine Kinney yönteminde frekans faktörünün etkisiyle, iş yerinde riskin yaşanma sıklı̆̆ı da ele alındığından daha iyi sonuçlar elde edilebilmektedir (Okumuş ve Barlas, 2016). Ayrıca yöntem, işyerinin istatistik verilerinin kullanılması nedeniyle daha geçekçi sonuçlara ulaşılabilmesini sağlamaktadır (Erzurumluoğlu vd., 2015). Çalışmada, kullanılan bu iki yöntemden hangisinin daha net ve gerçekçi sonuçlar verdiği, analizlerden elde edilen risk dereceleri, alınacak önlemler ve önlemlerin ne kadar yararlı olabileceği durumuna göre değerlendirilmiştir. Buna göre, tehlikeli atık bertaraf tesislerinde, riskleri detaylandırılarak incelemesi ve gerçeğe yakın sonuçlar vermesi nedeniyle Fine Kinney yönteminin daha uygun olduğu sonucuna ulaşılmıştır.

\section{Sonuç}

Yapılan bu çalışmada, artan sanayileşmenin sonucu olarak yaygınlaşan tehlikeli atık tesislerinde meslek hastalıklarının oluşmasına sebep olan biyolojik risk faktörleri ile fiziksel, kimyasal ve biyolojik faktörler açısından genel risk faktörleri değelendirilmiştir. Çalışmada öncelikle biyolojik risk faktörlerinin meslek hastalıkları ile olan ilişkisi araştırılmıştır. Biyolojik risk faktörlerinin meslek hastalıkları ile ilişkili olduğu fakat herhangi bir meslek hastalığına neden olmayacağı tespit edilmiştir. Bununla birlikte, biyolojik risk faktörleri açısından 5x5 L Tipi Matris yöntemi kullanılarak bir risk analizi yapılmış ve en fazla orta düzeyde risklerin bulunduğu belirlenmiştir. Biyolojik faktörlerin yanı sıra riskler genel olarak değerlendirilmiş ve iki farklı yöntemle analiz edilmiştir. Genel riskler oluşturulurken 5x5 L Tipi Matris ve Fine Kinney yöntemleri kullanılmıştır. Genel değerlendirmede 47 adet risk bulunmuş ve alınması gereken önlemler belirlenmiştir. Elde edilen sonuçlar yöntemler açısından karşılaştırıldığında, Fine Kinney yönteminin basit, kolay ve anlaşılabilir olması, üç faktörün olasılık, frekans ve şiddet parametrelerinin çarpılarak risklerin derecelendirilmesi, her sektöre uygulanabilmesi, gerçekçi sonuçlar vermesi gibi avantajları göz önünde bulundurularak Fine Kinney yönteminin atık bertaraf tesislerinde kullanılmasının uygun olacağı önerilmiştir. 


\section{Kaynakça}

Akgün, S. (2006). Sanayileşme Sürecinde Çevre Kalitesine Verilen Önem; Firmaların Yaklaşımları, Yüksek Lisans Tezi, Ege Üniversitesi.

Akkuş, E. (2013). Tehlikeli Atık Geri Kazanım Tesisinde İ̧̧ Să̆lı̆̆ı Güvenliğii, Yüksek Lisans Tezi, Aksaray Üniversitesi.

Demirel, H. (2016). Demir Yolu Makas Üretiminde Risk Değerlendirmesi, İş Sağlığı ve Güvenliği Uzmanlık Tezi, Çalışma ve Sosyal Güvenlik Bakanlığı, İş Sağlığı ve Güvenliği Genel Müdürlüğü.

Demirel, S. \& Sert, N. (2018). Bir Plastik Geri Dönüşüm Tesisinde Ön Tehlike Analizi (PHA) ile Risk Değerlendirmesi, Ömer Halisdemir Üniversitesi Mühendislik Bilimleri Dergisi, 7(2), 572-580.

Ercan, M. (2006). Tehlikeli Atık Bertaraf Tesislerinin İşS Sağllğı ve Güvenliği Yönünden İncelenmesi, İş Sağlı̆̆ı ve Güvenliği Uzmanlık Tezi, Çalışma ve Sosyal Güvenlik Bakanlı̆̆ı, İş Sağlığı ve Güvenliği Genel Müdürlüğü.

Erzurumluoğlu, K., Köksal, K.N., Gerek, İ.H. (2015). İnşaat Sektöründe Fine-Kinney Metodu Kullanılarak Risk Analizi Yapılması, 5. İş̧̧i Sağglı̆̆ ve İş Güvenliği Sempozyumu, 137-146, İzmir, Türkiye.

Karagözoğlu, B.M., Özyonar, F., Yılmaz, A., Atmaca, E. (2009). Katık Atıkların Yeniden Kazanımı ve Önemi, Türkiye'de Katı Atık Yönetimi Sempozyumu, İstanbul, Türkiye.

Kayhan, E. \& Demirer, A. (2016). Polimer İşleme Sektörlerindeki Meslek Hastalıkları, Kazalar ve İş Güvenliği, Sakarya Üniversitesi Fen Bilimleri Enstitüsü Dergisi, 20(3), 497-507.

Okumuş, D. \& Barlas, B. (2016). Gemi İnşaatı Sektöründe 5x5 Analiz Matrisi ve Fine-Kınney Yöntemlerinin Uygulamalı Bir Karşılaştırması, Gemi ve Deniz teknolojisi Dergisi, 204-205, 95-106.

Oturakçı, M. \& Dağsuyu, C. (2017). Risk Değerlendirmesinde Bulanık Fine-Kinney Yöntemi ve Uygulaması, Karaelmas Işs Sağllğı ve Güvenliği Dergisi, 1(1), 17-25.

Ölçücü Şensoy, H. (2019). Tehlikeli Atık Bertaraf Tesislerinde Meslek Hastalı̆̆ı ve Biyolojik Faktörler Açısından Risk Değerlendirmesi, Yüksek Lisans Tezi, Tarsus Üniversitesi.

Şengöz, M.C. \& Merdan, M. (2017). Fine-Kinney Risk Analizi Metoduyla, İşyerlerinde Elektrik Nedenli Yangınların Önlenmesinde Yeni Bir Yöntem, Gazi Mühendislik Bilimleri Dergisi, 3(3), 74-82.

Usanmaz, D. \& Köse, E. (2019). Karşılaşıırmalı Risk Analizi Metotlarının Bir Araştırma Merkezi İçin Uygulanması ve Sonuçların Değerlendirilmesi, 2. International Mediterranean Symposium, 1, 140-158, Mersin, Türkiye.

Zaloğlu, D.I. (2019). İş Să̆llğı ve Güvenliği Kapsamında Fosil Lokalitesinde Fine Kınney Metodu ile Risk Değerlendirmesi, Yüksek Lisans Tezi, Başkent Üniversitesi. 